\title{
Image Analysis of Root Induction in Sedum praealtum Cuttings
}

\author{
Ana K. Hernández-Zamora, Angélica Rodríguez-Dorantes
}

\section{ABSTRACT}

Production of adventive roots is a process induced and regulated by phytohormones where auxins play an important role in controlling the growth and development of them, with a direct influence on the regenerative ability of plants. The aim of this study was to compare the root induction and development on Sedum praealtum cuttings by the action of 3-indolylbutyric acid (IBA) and naphthylacetic acid (NAA) concentrations by root image analysis. Root length of plantlets showed that there was an interval between 0.1 and $1.0 \mathrm{mg} / \mathrm{L}$ concentrations of efficient root induction with a clearly decrease of it as IBA concentration increased, also as NAA treatment showed. In this work, the rooting response of Sedum praealtum cuttings evaluated by root image analysis showed the application of IBA as an efficient synthetic auxin for vegetative propagation.

Keywords: Sedum praealtum, cuttings, plant growth regulators, roots.
Published Online: November 30, 2020

ISSN: 2684-5199

DOI : 10.24018/ejbio.2020.1.6.128

Ana K. Hernández-Zamora

Escuela Nacional de Ciencias Biológicas, Instituto Politécnico Nacional, CDMX, México.

Angélica Rodríguez-Dorantes*

Escuela Nacional de Ciencias Biológicas,

Instituto Politécnico Nacional, CDMX, México.

(e-mail: rodorantes@ ${ }^{@}$ ahoo.com.mx)

*Corresponding Author

\section{INTRODUCTION}

Production of adventive roots is a process induced and regulated by plant growth regulators and it has a direct influence on the regenerative ability of the plant. Auxins play an important role in controlling the growth and development of the plants; particularly, in primary, secondary and adventitious roots production [1] and they are currently employed for rooting of cuttings. Synthetic 3indolylbutyric acid (IBA) has been the most commonly used auxin, because it promotes the production of adventitious roots compared to natural indolyl-3-acetic acid (IAA). Another relatively common synthetic auxin employed is $\alpha$ naphthylacetic acid (NAA); even it is not so effective on plant rooting, it possesses the advantage of lower price [2]. The genus Sedum (Crassulaceae) comprises almost 400 species, distributes all over the world except Australia and the Pacific islands and some of them are known as CAM (Crassulacean Acid Metabolism) plants [3]-[5]. There has been an important report about Sedum roseum and Sedum drymarioides regeneration [6], [7], and also a study about the efficient micropropagation system of Sedum alfredii, as a plant hyperaccumulator of zinc and cadmium [8]-[10]. Considering the importance to the establishment of vegetative propagation of some species of this genus, the aim of this study was to compare the effect of IBA and NAA plant growth regulators on Sedum praealtum roots induction, by root image analysis.

\section{MATERIALS AND METHODS}

\section{A. Plant Root Induction of Sedum praealtum}

Among 25 selected Sedum praealtum plants were collected from the gardens of E.N.C.B. and $5 \mathrm{~cm}$ of length cuttings were obtained from these plants containing buds and 3 leaves. These were surface sterilized at stem cut zone with sodium hypochlorite $(10 \%)$ for 5 minutes, rinsed with sterile distilled water and placed separately in sterile baby food flasks with Magenta SIGMA caps containing $90 \mathrm{~mL}$ of concentrate mineral medium $\left(0.20 \mathrm{M} \mathrm{NH}_{4} \mathrm{H}_{2} \mathrm{PO} 4,1.15 \mathrm{M}\right.$ $\mathrm{Ca}\left(\mathrm{NO}_{3}\right)_{2}, 0.26 \mathrm{M} \mathrm{CaCl}_{2}, 0.40 \mathrm{M} \mathrm{MgSO}{ }_{4} 7 \mathrm{H}_{2} \mathrm{O}, 1.2 \mathrm{M}$ $\mathrm{KNO}_{3}, 1.2 \times 10^{-2} \mathrm{M} \mathrm{H}_{3} \mathrm{BO}_{3}, 1.2 \times 10^{-4} \mathrm{M} \mathrm{CuCl}_{2} \cdot \mathrm{H}_{2} \mathrm{O}, 2.3 \times$ $10^{-3} \mathrm{M} \mathrm{ZnCl}_{2}, 4.4 \times 10^{-4} \mathrm{M} \mathrm{MnCl}_{2} \cdot 4 \mathrm{H}_{2} \mathrm{O}, 6 \times 10^{-6} \mathrm{M}$ $\mathrm{Na}_{2} \mathrm{MoO}_{4} \cdot \mathrm{H}_{2} \mathrm{O}, 7.2 \times 10^{-3} \mathrm{M}$ EDTA-Na 2 and $7.1 \times 10^{-3} \mathrm{M}$ $\mathrm{FeSO}_{4} \cdot 7 \mathrm{H}_{2} \mathrm{O}, \mathrm{pH}= \pm 6.0$ ). Control plants cuttings were considered without plant growth regulators added and the root induction was considered adding IBA at 0.1, 0.5, 1.0, 1.5, 2.0 and $3.0 \mathrm{mg} / \mathrm{L}$ concentrations, also NAA was tested only at $1 \mathrm{mg} / \mathrm{L}$ concentration. All of these hydroponic cultures were cover with paper favoring the root induction and growth, performed by triplicate and maintained under greenhouse conditions for 30 days. At the end of this time, plants were obtained, and each was analyzed regarding to their development in each experimental condition. At first, roots images were obtained using Kodak Easyshare C713 Zoom Digital Camera and these images were analyzed employing the Motic Image 2000 Software Ver. 1.3, standardizing their size and after all the roots developed were lineally measured and the summary of all were obtained. 


\section{B. Statistical Analysis}

All data were analyzed by one-way analysis of variance and the mean differences were compared applying a TukeyKramer Method using the statistics program Graph Pad Instat Ver. 2.03. The relationship between root length and roots number obtained in each experimental condition was also analyzed by regression analysis using the Paleontological Statistics Software PAST Ver. 2.17b.

\section{RESULTS}

\section{A. Root induction in Sedum prealtum cuttings}

Fig. 1 shows the experimental conditions tested for $S$. praealtum cuttings; these were organized inside a chamber under greenhouse conditions (Fig. 1a) and flasks were covered to avoid light interferences on root induction. Fig. $1 \mathrm{~b}$ shows how root images were processed and analyzed by Motic Image Software.

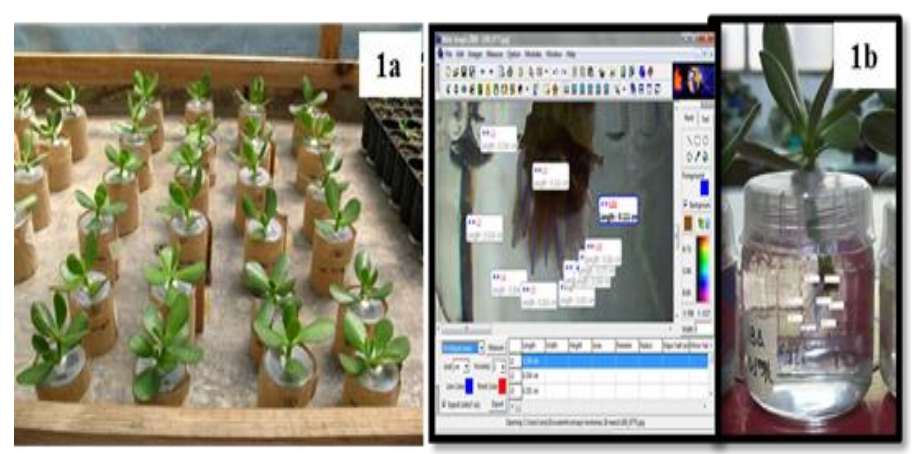

Fig. 1. Sedum praealtum cuttings and analysis:

a) Cuttings grown in hydroponic cultures collocated in a chamber under greenhouse conditions. b) Motic image analysis of roots.

The effect of IBA on $S$. praealtum induction showed that the number of roots increased in $0.1,1.0$ and $2 \mathrm{mg} / \mathrm{L}$ concentrations compared to control plant cuttings, where the number of roots diminished as NAA experiments (Fig. 2).

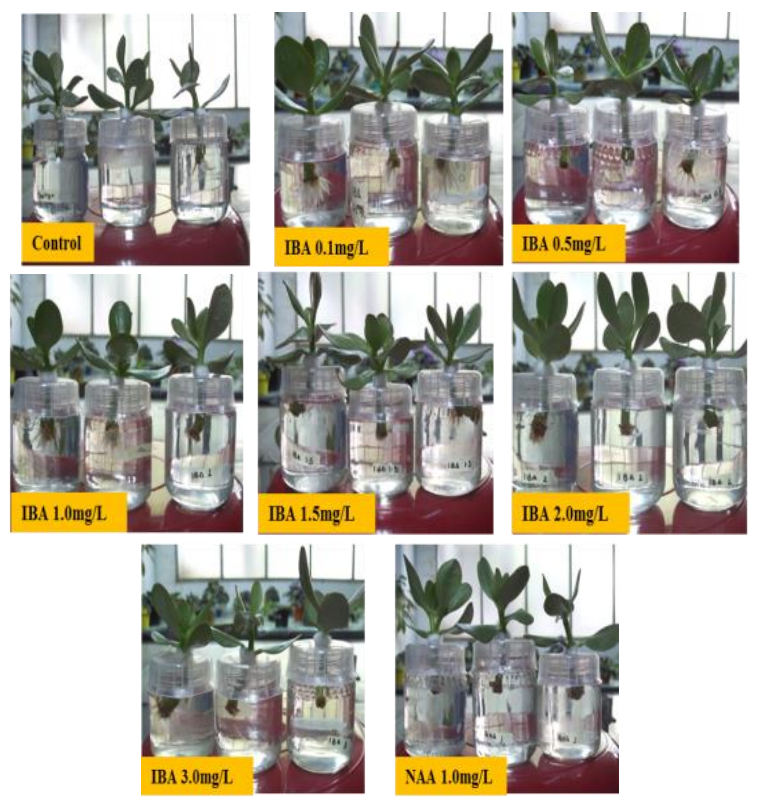

Fig. 2. Roots development and appearance of Sedum praealtum plantlets grown hydroponic cultures.
Root length of $S$. praealtum plantlets showed that there was an interval between 0.1 and $1.0 \mathrm{mg} / \mathrm{L}$ concentrations of efficient root induction; clearly the increase in IBA concentration decrease the length of roots as control and NAA did, with a statistical significance between them (Fig. $3 a, p<0.001)$. Fig. $3 b$ shows the correlation between root length and roots number obtained in each experimental condition; with an evident behavior of two middle IBA concentrations tested $(0.1$ and $1.0 \mathrm{mg} / \mathrm{L})$ and the diminished effect of the increased IBA concentrations (1.5, 2.0 and $3.0 \mathrm{mg} / \mathrm{L})$.
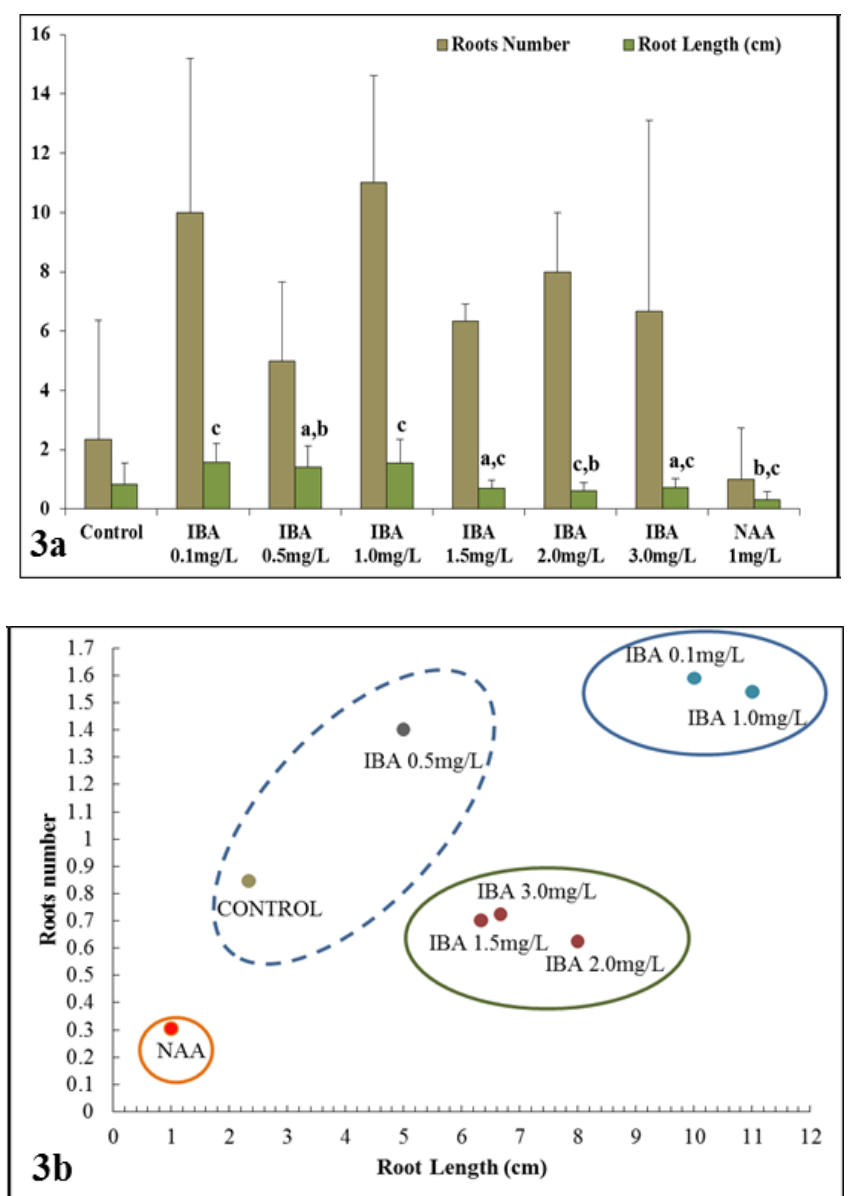

Fig. 3. Sedum praealtum analysis of plantlets: 3a) number and length of roots obtained in each experimental conditions $(n=16$, the different lower-case letters shows the significant differences founded $[\mathrm{p}<0.001])$ and $3 b$ ) linear regression curve showing the relationship between roots number and root length $(r=0.66)$.

It is important to note that even the high number of roots produced, these were shortly and thick with necropsied apical meristems as the appearance obtained with NAA; where this plant growth regulator slightly diminished the number of roots produced in $S$. praealtum cuttings. The particular response of $S$. praealtum root length profiles in Fig. 4, reveals that this parameter was more continuous between cuttings tested in $0.1 \mathrm{mg} / \mathrm{L}$; compared to cuttings in $1.0 \mathrm{mg} / \mathrm{L}$ of IBA plant growth regulator, with a better growth of plants in the lowest concentration. 


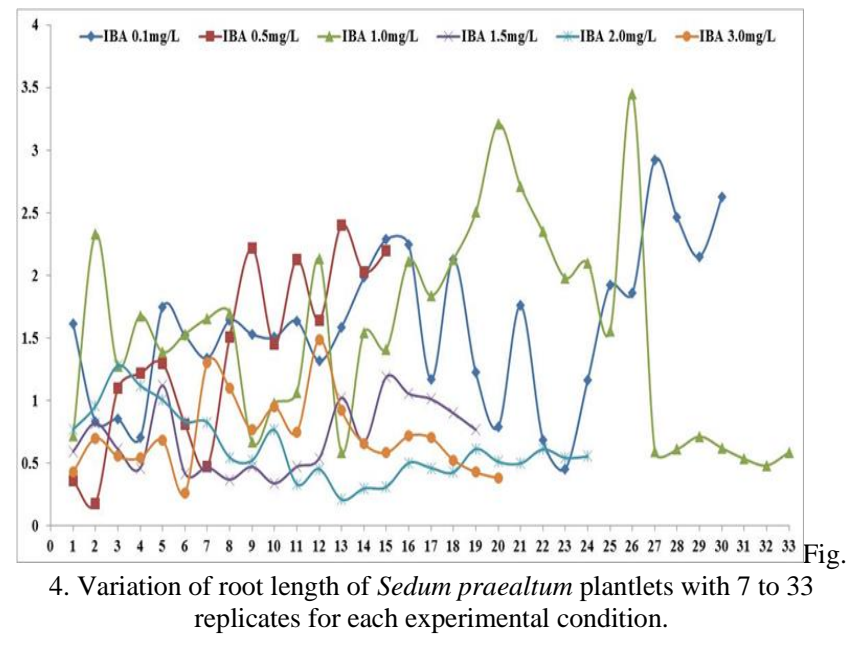

\section{DISCUSSION}

The effects of auxin group of phytohormones on rooting and plant development have been discussed in several studies: Śtefančič et al. [11] studied the effectiveness of IBA and NAA in Pseudotsuga menziesii; Hossain et al. [12] analyzed the effectiveness of IBA in Swietenia macrophylla and Chukrasia velutina; Chhun et al. [13] researched the effectiveness of IAA, IBA, and NAA in Oryza sativa; deKlerk et al. [14] analyzed the effectiveness of IAA, IBA, and NAA in Malus sp.; Martin [15] studied the effectiveness of IBA in Holostemma addkodien; Tchoundjeu et al. [16] analyzed the effectiveness of IBA in Prunus Africana; Swamy et al. [17] studied the effectiveness of IBA and NAA in both Robinia pseudoacacia and Grewia optiva. All of these studies show in general auxin group of hormones has an open and wide effect on plants rooting initiation. Thus, adventitious root formation is influenced by internal and external factors were natural and synthetic auxins regulated this process [18]. Particularly, Zhao et al. [19] analyzed the efficient regeneration system of Sedum alfredii using stem and leaf tissues; they reported that this three plant growth regulators: IBA, IAA, and NAA, induced rooting of elongated shoots within a period of 2 weeks. However, differences in efficiency of rooting induction were observed among them: IBA induced the highest frequency of rooting (100\%) at all tested concentrations $(0.1,0.5,1.0$, $1.5,2.0$ and $3.0 \mathrm{mg} / \mathrm{L}$ ), followed by IAA and then NAA, authors also noted roots induced by NAA, at 0.1, 0.5, 1.0, 2.0 and $3.0 \mathrm{mg} / \mathrm{L}$ concentrations, were rather short, thick and plantlets were grown slowly. In this work, S. praealtum plantlets showed a similar response compared to $S$. alfredii regarding to the efficiency of IBA, but only at lowest concentrations tested.

\section{CONCLUSION}

Vegetative propagation of some species ensures the preservation of all characteristics of the parent plant and depends on the regeneration ability and growing of adventitious roots in plant cuttings. In this work, the rooting response of Sedum praealtum cuttings evaluated by root image analysis showed the application of indolylbutyric acid was an efficient synthetic auxin for its vegetative propagation.

\section{ACKNOWLEDGMENT}

Authors are grateful to the Research Projects SIP: 20121516 and SIP: 20131494 of the Secretaría de Investigación y Posgrado del Instituto Politécnico Nacional, and for the COFAA-IPN, EDI-IPN and SNI-CONACYT fellowships.

\section{REFERENCES}

[1] Salaš, P., Saskova, H., Mokričkova, J. \& Litschmann, T. (2012): Evaluation of different types stimulators. Acta Universitatis Agriculturae et Silviculturae Mendelianae Brunensis 60, 217-228.

[2] Pop, T., Pamfil, D. \& Bellini, C. (2011): Auxin control in the formation of adventitious roots. Notulae Botanicae Horti Agrobotanici Cluj Napoca. 39, 307-316.

[3] Osmond, C.B. \& Ziegler, H. (1975): Carbon isotope discrimination in alpine succulent plants supposed to be capable of crassulacean acid metabolism (CAM). Oecologia. 18, 209-217.

[4] Kluge, M. (1977): Is Sedum acre L. a CAM plant?. Oecologia. 29, 7783.

[5] Kluge, M. \& Ting, I.P. (1978): Crassulacean Acid Melabolism Analysis of an Ecological Adaptation. Springer Verlag GmbH\&Co. KG., Berlín.

[6] Furmanowa, M., Oledzka, H., Michalska, M., Sokolnicka, I. \& Radomska, D. (1995): Rhodiola rosea L. (Roseroot): in vitro regeneration and the biological activity of roots. In: Bajaj, Y.P.S. (Ed.), Biotechnology in Agriculture and Forestry. Springer Verlag, Berlín Heidelberg. 33, 412-426.

[7] Kitamura Y., Kubo, K., Rahman, L. \& Ikenaga, T. (2002): Reproduction of Sedum drymarioides, an endangered rare species, by micropropagation. Plant Biotechnology. 19, 303-309.

[8] Long, X.X., Yang, X.E., Ye, Z.Q., Ni, W.Z. \& Shi, W.Y. (2002): Differences of uptake and accumulation of zinc in four species of Sedum. Acta Botanica Sinica. 44,152-157.

[9] Ni, T.H. \& Wei, Y.Z. (2003): Subcellular distribution of cadmium in mining ecotype Sedum alfredii. Acta Botanica Sinica. 45, 925-928.

[10] Ye, H.B., Yang, X.E., He, B., Long, X.X. \& Shi, W.Y. (2003): Growth response and metal accumulation of Sedum alfredii to $\mathrm{Cd} / \mathrm{Zn}$ complex polluted ion levels. Acta Botanica Sinica. 45, 1030-1036.

[11] Śtefančič, M., Śtampar, F. \& Osterc, G. (2005): Influence of IAA and IBA on root development and quality of Prunus "GiSelA5" leafy cuttings. HortScience. 40, 2052-2055.

[12] Hossain, M.A., Islam, M.A. \& Hossain, M.M. (2004): Rooting ability of cuttings of Swietenia macrophylla King and Chukrasia velutina Wight et Arn as influenced by exogenous hormone. International Journal of Agriculture \& Biology. 6, 560-564.

[13] Chhun, T., Taketa, S., Tsurumi, S. \& Ichii, M. (2003): The effects of auxin on lateral root initiation and root gravitropism in a lateral rootless mutant Lrt1 of rice (Oryza sativa L.). Plant Growth Regulation. 39, 161-170.

[14] de Klerk, G.J., Ter Brugge, J. \& Marinova, S. (1997): Effectiveness of indoleacetic acid, indolebutyric acid and naphthaleneacetic acid during adventitious root formation in vitro in Malus 'Jork 9'. Plant Cell, Tissue and Organ Culture. 49, 39-44.

[15] Martin, K.P. (2002): Rapid propagation of Holostemma ada-kodien Sehult., a rare medicinal plant, through axillary bud multiplication and indirect organogenesis. Plant Cell Reports. 21, 112-117.

[16] Tchoundjeu, Z., Avana, M.L., Leakey, R.R.B., Simons, A.J., Asaah, E., Duguma, B. \& Bell, J.M. (2002): Vegetative propagation of Prunus africana: effects of rooting medium, auxin concentrations and leaf área. Agroforestry Systems. 54, 183-192.

[17] Swamy, S.L., Puri, S. \& Singh, A.K. (2002): Effect of auxins (IBA and NAA) and season on rooting of juvenile and mature hardwood cuttings of Robinia pseudoacacia and Grewia optiva. New Forests. 23, 143-157.

[18] Sevik, H. \& Guney, K. (2013): Effects of IAA, IBA, NAA, and GA 3 on rooting and morphological features of Melissa officinalis L. stem cuttings. The Scientific World Journal. 1, 909507

[19] Zhao, S.J., Zhang, Z.Ch., Gao, X., Tohsun, G. \& Qiu, B.Sh. (2009): Plant regeneration of the mining ecotype Sedum alfredii and cadmium hyperaccumulation in regenerated plants. Plant Cell, Tissue and Organ Culture. 99, 9-16. 